\title{
Learner expectations and satisfaction in a US-Spain intercultural telecollaboration project
}

\author{
Ana Gimeno \\ Universitat Politècnica de València
}

(Text received July 03 2018; accepted July 04 2018; final version September 29, 2018)

DOI: http://doi.org/10.5565/rev/jtl3.776

\begin{abstract}
The focus of this paper is the analysis of data collected after conducting a telecollaboration project throughout one semester with 12 advanced learners of Spanish from a mid-sized Atlantic coast university in the USA and 12 higher intermediate students of English from a technical university in Spain. Data was collected through a questionnaire enquiring about learner expectations at the outset of the project and a final survey seeking detailed information about learner satisfaction in order to implement improvements in subsequent projects. In-depth analysis of the data also shed light on the perceived benefits and challenges of the intercultural telecollaboration project. There was evidence that the students were very open-minded about discussing multifaceted intercultural issues and very positive toward collaborating with fellow students from a different cultural background. The surveys also suggest that the learners' expected benefits aligned with their stated benefits after carrying out the project, which led us to believe that possible frustrations and communication breakdowns had been kept to a minimum.
\end{abstract}

Keywords: telecollaboration, intercultural exchanges; learner expectations; learner satisfaction, English as a foreign language, Spanish as a foreign language

Resum: L'enfocament d'aquest article és l'anàlisi de dades recollides després de realitzar un projecte de tele-col·laboració al llarg d'un semestre amb 12 estudiants avançats d'espanyol provinents d'una universitat mitjana de la costa atlàntica dels EUA i 12 estudiants de nivell intermedi-alt d'anglès d'una universitat tècnica a Espanya. Les dades es van recollir mitjançant un qüestionari sobre les expectatives dels alumnes al principi del projecte i una enquesta final que buscava informació detallada sobre la satisfacció de l'alumne per tal d'implementar millores en projectes posteriors. L'anàlisi en profunditat de les dades posa de manifest els beneficis i els desafiaments percebuts del projecte de tele-col-laboració intercultural. Hi va evidència que els estudiants estan molt oberts per discutir qüestions interculturals multifacètiques i per col·laborar amb companys d'un context cultural diferent. Les enquestes també suggereixen que els beneficis esperats pels estudiants s'alineen amb els seus beneficis declarats després de dur a terme el projecte, la qual cosa ens porta a creure que s'han reduït al mínim possibles frustracions $\mathrm{i}$ problemes de comunicació.

Paraules clau: tele-col·laboració; intercanvis interculturals; expectatives de l'aprenent; satisfacció de l'aprenent; Anglès com a Llengua Estrangera; Espanyol com a Llengua Estrangera 
Resumen: El enfoque de este artículo es el análisis de datos recogidos después de realizar un proyecto de telecolaboración a lo largo de un semestre con 12 estudiantes avanzados de español provenientes de una universidad media de la costa atlántica de EE.UU. y 12 estudiantes de nivel intermedio-alto de inglés de una universidad técnica en España. Los datos se recogieron mediante un cuestionario sobre las expectativas de los alumnos al principio del proyecto y una encuesta final que buscaba información detallada sobre la satisfacción de los alumnos con el fin de implementar mejoras en proyectos posteriores. El análisis de los datos en profundidad pone de manifiesto los beneficios y los desafíos percibidos en el proyecto de telecolaboración intercultural. Muestra evidencias de que los estudiantes están muy abiertos para discutir cuestiones interculturales multifacéticas y para colaborar con compañeros de un contexto cultural diferente. Las encuestas también sugieren que los beneficios esperados por los estudiantes se alinean con sus beneficios declarados después de llevar a cabo el proyecto, lo que nos lleva a pensar que se han reducido al mínimo posibles frustraciones y problemas de comunicación.

Palabras clave: telecolaboración; intercambios interculturales; expectativas del aprendiz; satisfacción del aprendiz; Inglés como Lengua Extranjera; Español como Lengua Extranjera.

\section{Background}

In this paper we shall refer to telecollaboration as defined by Guth and Helm in 2010 (p. 14); that is, as an "internet-based intercultural exchange between people of different cultural/national backgrounds set up in an institutional context with the aim of developing both language skills and intercultural communicative competence through structured tasks". Throughout these past years, an increasing amount of research into telecollaboration has been conducted that has reported on the many gains in areas such as language development (Hauck \& Youngs, 2008; Kern, Ware, \& Warschauer, 2004), learner autonomy (O'Rourke, 2007), and intercultural communicative development (Fuchs, 2007; Oskoz, Gimeno \& Sevilla, 2018) which have exceeded the challenges that may arise, among other things, from differing interactional styles, incompatibilities in world interpretations, and socio-institutional constraints (Basharina, 2007; Ware \& Kramsch, 2005; Ware \& O’Dowd, 2008). In these telecollaborative encounters, learners synchronously or asynchronously engage with one another in dyads, triads, or small groups (Helm, 2016) to participate in different tasks that often entail a cultural discussion. Interactions have commonly made use of synchronous online tools, such as chats (Belz, 2003; Kohn \& Hoffstaedter, 2017; Müller-Hartmann, 2006) and video conferencing (Helm, 2013; Sevilla-Pavón \& Haba, 2016), or asynchronous tools, such as wikis and blogs (Elola \& Oskoz, 2008; Guth \& Marini-Maio, 2010; Hauck \& Youngs, 2008; Lee, 2009, 2010, 2011), email (Fuchs, Snyder, Tung, Jung, \& Snyder, 2017; O’Dowd, 2007; O’Dowd \& Ritter, 2006; Turula, 2017; Ware \& O’Dowd, 2008), and online forums (Chun, 2011; Liaw \& Master, 2010). Despite being considered a 
more traditional tool, online forums provide "a critical common space in which [to] share and verify hypotheses and points of view, to ask for help deciphering meanings of words and concepts, and to constantly negotiate meanings and interpretations" (Bauer, de Benedette, Furstenberg, Levet, \& Waryn, 2006, p. 35). Thus, they have been instrumental in enhancing students' cultural reflections (Bauer et. al, 2006; WildnerBassett, 2005; Oskoz, 2012; Oskoz \& Pérez-Broncano, 2016).

As pointed out by Oskoz (2012) and Wertsch (1991, 1998), these asynchronous online interactions are dialogic in essence (Bakhtin, 1986) basically because the L2 learners interact with each other, they engage in discussions and expect contributions from their counterparts to enhance the content of the debate. However, it was Freire (1970) who wisely pointed out that dialogue is not "the act of one person's 'depositing' ideas in another, nor can it become a simple exchange of ideas to be 'consumed' by the discussants" (p. 70). It implies actively listening to different perspectives in which conflict, not confrontation, is seen as a transformative agent. Additionally, as argued by Depalma (2010), one of the advantages of using online forums to foster these dialogic exchanges is that, given the slower pace of asynchronous online communication, learners have the opportunity of reading their peers' comments, plan their response, find additional information to support or refute previous statements, and develop sometimes in an informal style- a coherent reply that includes both external voices and those of their counterparts. Moreover, in online forums, learners tend to present their own points of view on the issue being discussed much as they would in face-to-face interactions, a practice that requires the writer to have the ability to "interpret phenomen[a] and exercise some form of evaluative judgment on the basis of desirability, belief, or the criteria" (Chandrasegaran \& Kong, 2006, p. 377).

Telecollaborative encounters have often been criticised for turning to "safe topics" as the stimulus for arousing online discussions in order to avoid communication breakdowns (Helm, 2013). However, O'Dowd (2016) cautions that, although these topics may well be used as icebreakers, they will not likely encourage learners to move beyond information exchange and superficial cultural comparisons (Guth \& Helm, 2010; Schneider \& von der Emde, 2006). O’Dowd further questions the extent to which a telecollaborative exchange based on that limited type of interaction may even reinforce stereotypes, and warns us that "the outcomes of such trivial exchanges" might result in learners sidestepping differences "to focus instead on what cultures may have 
in common at a superficial level" (O’Dowd, 2016, p. 297). In line with this, Helm (2013) suggested the need to bring divisive and challenging topics that require learners to move out of their comfort zone and, with the help of the instructor, engage in a reflective dialogue.

\section{Project}

Participants. Two groups of learners, one from the Universitat Politècnica de València (Technical University of Valencia), Spain, and the other from the University of Maryland in Baltimore, USA, engaged in a telecollaborative encounter during one semester. There were twelve Spanish students, all of whom were majoring in aerospace engineering, who had enrolled in an optional 3rd-year 6-credit higher intermediate English-language class, and twelve North American students enrolled in a 3rd-year 3credit Spanish history and culture class as a requirement for their major or minor in Spanish. There were 12 male and 12 female students and they were between 17 and 24 years of age.

Tools. Out of the many free online discussion tools currently available, the instructors created a private community using Google+ and the students were each invited to join. Being as it was a closed community, this safeguarded the learners' privacy and, in some cases, unwillingness to share their profile with the outside world. Despite Google products being very popular, both in the US and Spain, not all of the participants had Google accounts prior to the project so those who did not, were required to register for one. The asynchronous nature of the postings was also a feature that the instructors sought in order to allow students time to think out and plan their responses (Guth \& Thomas, 2010).

In addition to written interaction, students were also requested to engage in 30minute synchronous sessions using Skype to conclude each of the 2-week forum discussions, as well as an introductory ice-breaking session and a farewell session. A total of 4 sessions were conducted by each group.

After each of the two online written discussions had concluded, each group was also requested to prepare a PowerPoint or Prezi sound-enhanced presentation for their counterparts to watch in class and comment on fluency, content and style. 
Audacity was the software chosen for students to create the main artefact to be peer-assessed, that is, a radiophonic podcast focussing on one of the topics discussed within the subject.

Lastly, SoundCloud was used in order to upload and share the podcasts for all the group members to listen to and assess.

Procedure. Organized into 6 groups, each with two participants from the USA and two from Spain, students initiated the project by introducing themselves to their counterparts in the forum. Subsequently, the students participated in three discussions, each of which took place over a period of two weeks, within the Google+ community. The first focused on the discussion of the TED Talk "The Danger of a Single Story" by novelist Chimamanda Adichie (2009). Discussions 2 and 3 focused, on the one hand, on immigration and, on the other, nationalism and patriotism. In order to allow all the students to interact in their target language, the discussion on immigration took place in Spanish and the discussion on nationalism/patriotism took place in English.

In order to boost debate, each of the cultural discussions were initiated in class and guided by the instructors, who also provided links and articles to start the conversation. Both groups used the same links and articles as a starting point. After the initial in-class conversation, learners continued the online discussion in their respective groups for two weeks. The two discussion topics addressed issues that were particularly significant at the time of the project, having a huge repercussion in the media in both countries ${ }^{1}$. Discussions continued throughout the two weeks in student-led teams. Following Arnold and Ducate (2006), Oskoz (2009, 2012), and Weasenforth, Biesenbach-Lucas \& Meloni (2002) each group was assigned a leader per topic whose mission was to initiate, maintain and close each of the discussions and summarize the comments posted by all of the other group members. All of the group members were also required to provide personal opinions and share personal experiences, integrate ideas from their classmates' contributions into their own comments, search for additional information, and ask questions that would help maintain the conversation. All of the learners were required to post a minimum of four comments per topic. Following Oskoz \& Pérez-Broncano's (2016) advice, the instructors discretely participated in the

\footnotetext{
${ }^{1}$ This was due to the presidential elections taking place in the USA when Donald Trump won and the debate in Spain regarding the independence of Catalonia.
} 
online discussions in order to encourage exchanges when any of the groups kept silent for too long and to bring different perspectives into the discussion.

\section{Research questions}

The research questions posed aimed at gathering relevant information in order to determine areas of improvement:

1. What are the learners' general expectations toward the telecollaboration project?

2. What are the perceived benefits and challenges of the telecollaboration project?

3. Have the learners' expectations been satisfied?

\section{Survey}

Before starting the telecollaboration exchange project, the instructors collected information on learner profile and expectations by means of a pre-project questionnaire. Upon completion, the learners again completed a questionnaire to gather relevant data regarding overall satisfaction, personal opinions and suggestions for improvement.

In total, 21 students completed the pre-questionnaire (10 from Spain and 11 from the US)

The initial questionnaire was divided into the following 5 parts and included 52 enquiry items based on a 7-point Likert scale plus 4 open-ended questions:

1. Demographics. (15 items)

2. Motivation toward language learning. The various uses and frequency in using ICT both as study tools and as leisure items. Their attitude toward working together with other students. Collaborating with international students. (10 items)

3. Their overall attitude toward Telecollaboration. (9 items)

4. Their level of cultural awareness. (18 items)

5. Their attitude toward learning languages in an intercultural setting. (4 items) The post-questionnaire was divided into the following 5 sections, with a total of 55 questions using a 7-point Likert scale and 10 open-ended questions:

1. Demographics. Use of the internet and social networks. Attitude toward the final project artefact - a radiophonic podcast (14 items)

2. Motivation toward language learning and ICT. Attitude toward working collaboratively with fellow students (9 items) 
3. Attitude toward the Telecollaboration project. (9 items)

4. Cultural awareness. (18 items)

5. Attitude toward learning languages in a multicultural setting. (15 items)

Each variable was composed of a number of defining items and analysed qualitatively and quantitatively.

\section{Results and discussion}

Pre-questionnaire. The pre-project questionnaire provided us with ample information in terms of learner profile and expectations.

Only 1 had previously created a podcast $(4.76 \%)$ and that same person was the only one that strongly agreed to the statement "Making a podcast for my language class would be fun" (Q12). Nearly half of them (47.62\%) had no opinion and just over a third (33.34\%) had a positive feeling about this. However, when asked if "Making a podcast would be a good way to show language knowledge" (Q13), the majority (85.72\%) agreed with this to some extent, contrary to believing that "Making a podcast would be a good way to show my cultural knowledge" (Q14), which only amounted to 2 thirds (66.68\%). Additionally, two thirds (66.67\%) agreed to being anxious about the thought of creating a podcast for class (Q15).

Except for 1 person, all of the others agreed to being motivated to learn English/Spanish at University.

Regarding use of technology to learn a foreign language (Q17), 4 of them had barely used technology for this purpose (19.04\%), whereas just over half of them $(52.38 \%)$ had. None of them manifested being against the use of ICT to learn a FL (Q18). Furthermore, they all that they would enjoy using ICT (Q19) and that it could help them develop their language skills.

When asked whether they enjoyed working with other students in the language class (Q21), 80.95\% said they did, while $14.29 \%$ were undecided about this and only 1 of them denied this. Just under a quarter (19.05\%) were unsure whether working with other students would help them learn the foreign language (Q22) but 71.44\% were favourable to this idea. Only 3 students (14.28\%) had any previous experience working with students from other countries through telecollaboration (Q23), while 76.19\% had never done this before. Strangely, 19.05\% were uncertain. 
When asked whether they preferred working on their own in class (Q25), there was a variety of responses and, therefore, no clear tendency:

\begin{tabular}{|c|c|c|c|c|c|c|c|c|}
\hline $\begin{array}{l}\text { STRONGLY } \\
\text { DISAGREE }\end{array}$ & DISAGREE & $\begin{array}{l}\text { TEND TO } \\
\text { DISAGREE }\end{array}$ & NEUTRAL & $\begin{array}{l}\text { TEND TO } \\
\text { AGREE }\end{array}$ & AGREE & $\begin{array}{l}\text { STRONGLY } \\
\text { AGREE }\end{array}$ & TOTAL & $\begin{array}{l}\text { WEIGHTED } \\
\text { AVERAGE }\end{array}$ \\
\hline $9.52 \%$ & $9.52 \%$ & $9.52 \%$ & $23.81 \%$ & $14.29 \%$ & $19.05 \%$ & $14.29 \%$ & & \\
\hline 2 & 2 & 2 & 5 & 3 & 4 & 3 & 21 & 4.38 \\
\hline
\end{tabular}

Figure 1. Responses to question 25 asking whether students preferred working on their own in the FL class

Although 3 students (14.29\%) did not have an opinion as to whether they would like to participate in a telecollaborative exchange (Q24), the vast majority were indeed all for it $(85.72 \%)$ and another $85.72 \%$ agreed that such a methodology would help them improve their language skills (Q26). Here again, 14.29\% were unsure. Nearly the same proportion was reported when they were asked whether they thought a telecollaborative exchange project would improve their cultural skills in the FL (Q27), i.e. $9.52 \%$ were uncertain and $90.48 \%$ had a favourable opinion. Furthermore, $76.19 \%$ thought it would be fun (Q28) but they did not see telecollaboration as helping them improve their ICT skills (Q29), i.e. 28.57\% were unsure about this and $71.43 \%$ were more optimistic about this. 


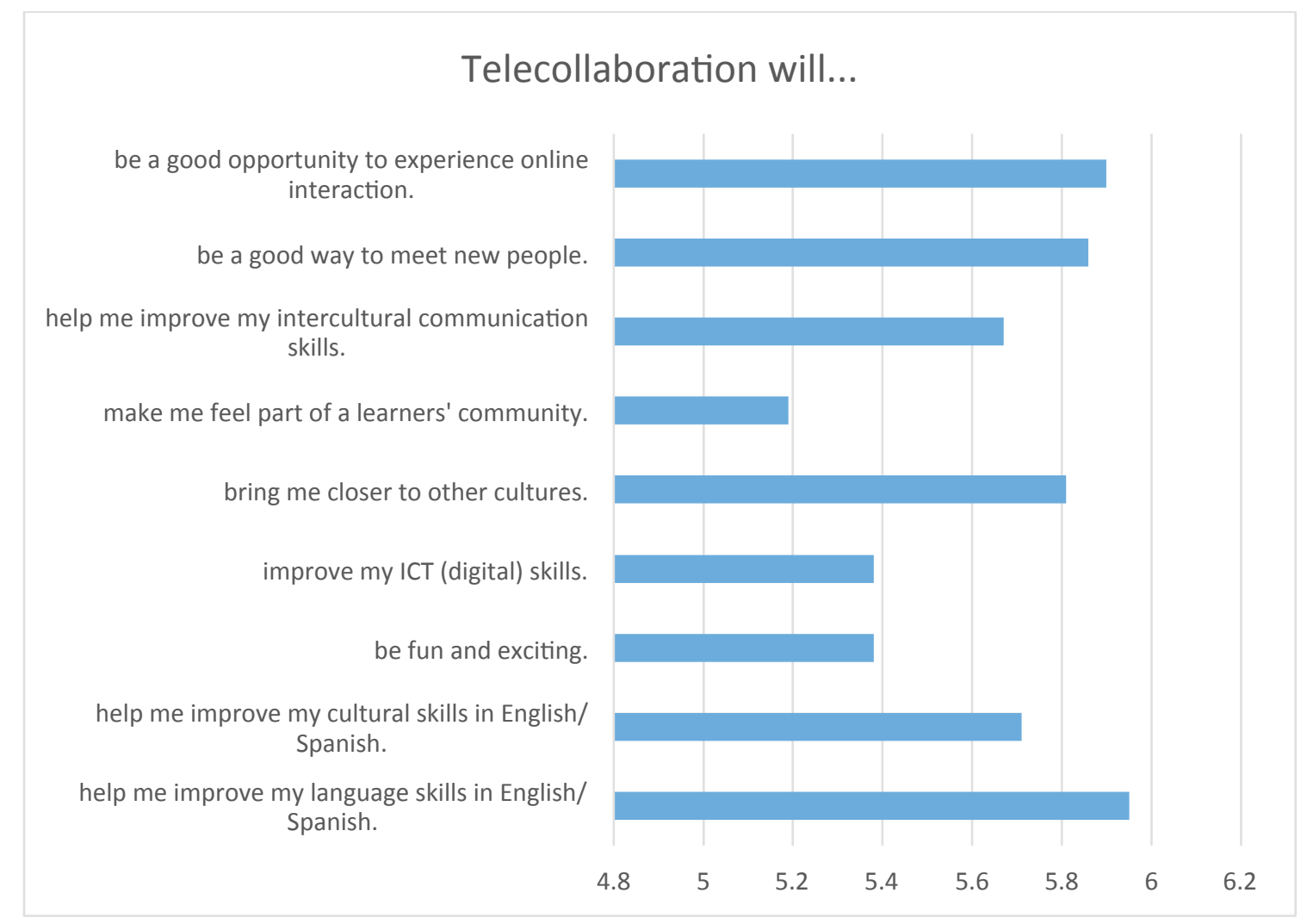

Figure 2. Student perception regarding the benefits of participating in a telecollaboration exchange project with overseas partners (out of a scale of 7)

As we can see, the three major benefits are perceived to be a) improving their FL skills; followed by b) experiencing real life interaction with native speakers of the FL they are seeking to improve; and, c) a chance to meet new people. Bring students closer to the L2 culture, which was one of the projects main aims, came in $4^{\text {th }}$ place out of the 9 suggested benefits.

Regarding the learners attitude toward interacting with people belonging to other cultures, overall, students from both sides of the Atlantic were very positive and were open-minded about this. However, it was a bit alarming to see that there were quite a few, in each of the attitudinal questions, who had no definite opinion. 


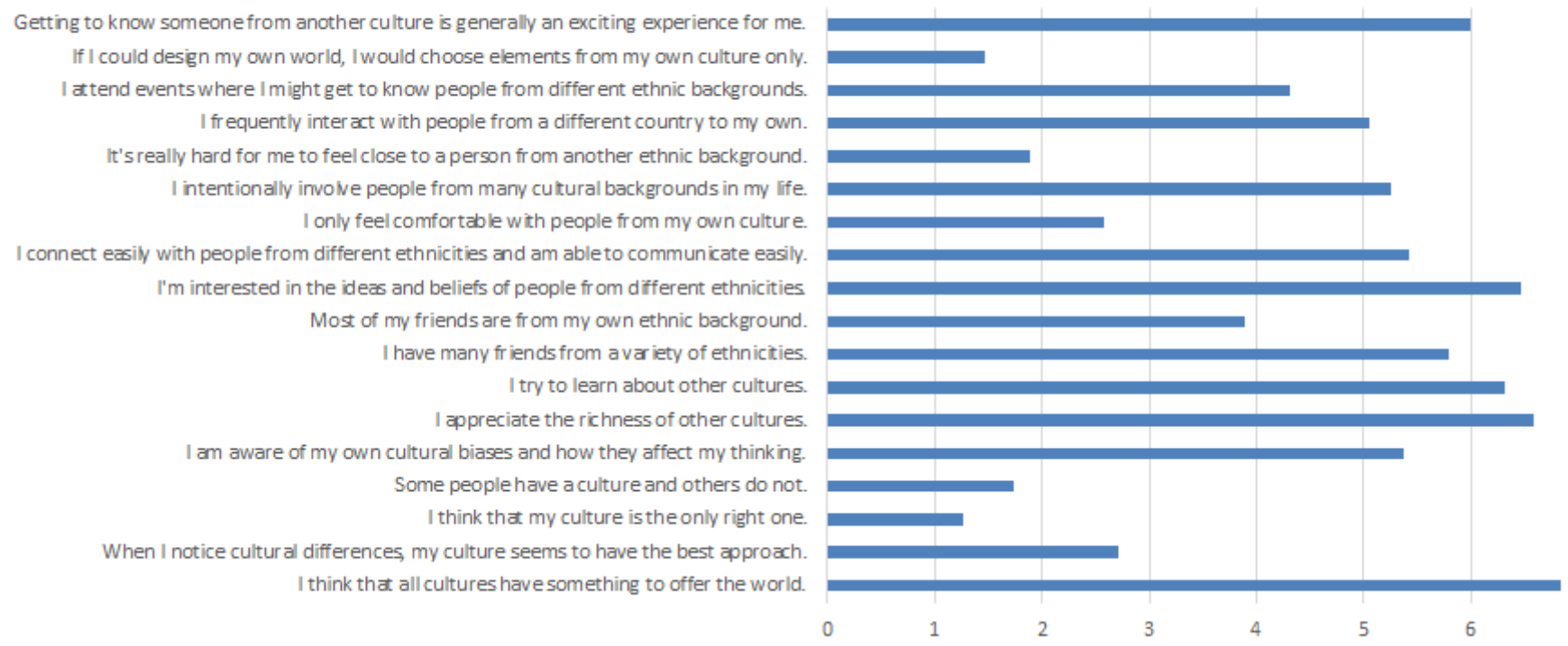

Figure 3. Learners's cultural awareness and attitudes towards other cultures

Regarding Q55, which queried about the learners' perceptions in terms of the potential challenges of participating in a diverse, multicultural setting to improve a FL, it was interesting to see that, despite the fact that our learners did envisage a few challenges, none of these were unsolvable. The following are examples of their uneasiness.

- Communication

- I think the first meeting will be the hardest because of the "shame".

- People are all at a different level speaking-wise and that could leave some people feeling left out.

- Certain words mean different things in different countries/cultures. It could potentially cause some awkward situations.

- The conversations between both groups of people

- I do not think there are many challenges if everyone tries to have a good communication.

- Make a fluent conversation in a language that is not my own (natively).

- If there are time differences (e-collaboration), language barriers.

- Having very strong opinions and not able to accept certain aspect of other cultures

\section{- Sometimes sentiments are not as easily translated}


- There will likely be somewhat of a language barrier - fluency will likely not be $100 \%$ between any of the students.

- My Spanish isn't at the level that I want it to be yet, but I am working hard every day toward my goal (fluency).

- Setting aside your own beliefs in order to be more receptive of other's.

- To get in touch with the other students.

- Tal vez tenga que ver las cosas desde la perspectiva de las personas que son diferentes a ti mismo.

- I do not think a multicultural environment for learning is more challenging than one that is not, maybe there is the language barrier but I do not think that is critic at the university level

In these explanations, we find three ideas interesting. Firstly, recognizing that being shy to speak face-to-face (via Skype) can become a handicap for successful communication; secondly, being aware that they may be confronted with intransigent counterparts; and lastly, that one of the most difficult things to transmit in a foreign language are feelings.

As we can see in Figure 4, all of the students perceived that participating in the Google+ private community that had been set up for the project would be helpful for all 11 items the instructors suggested in the survey. 


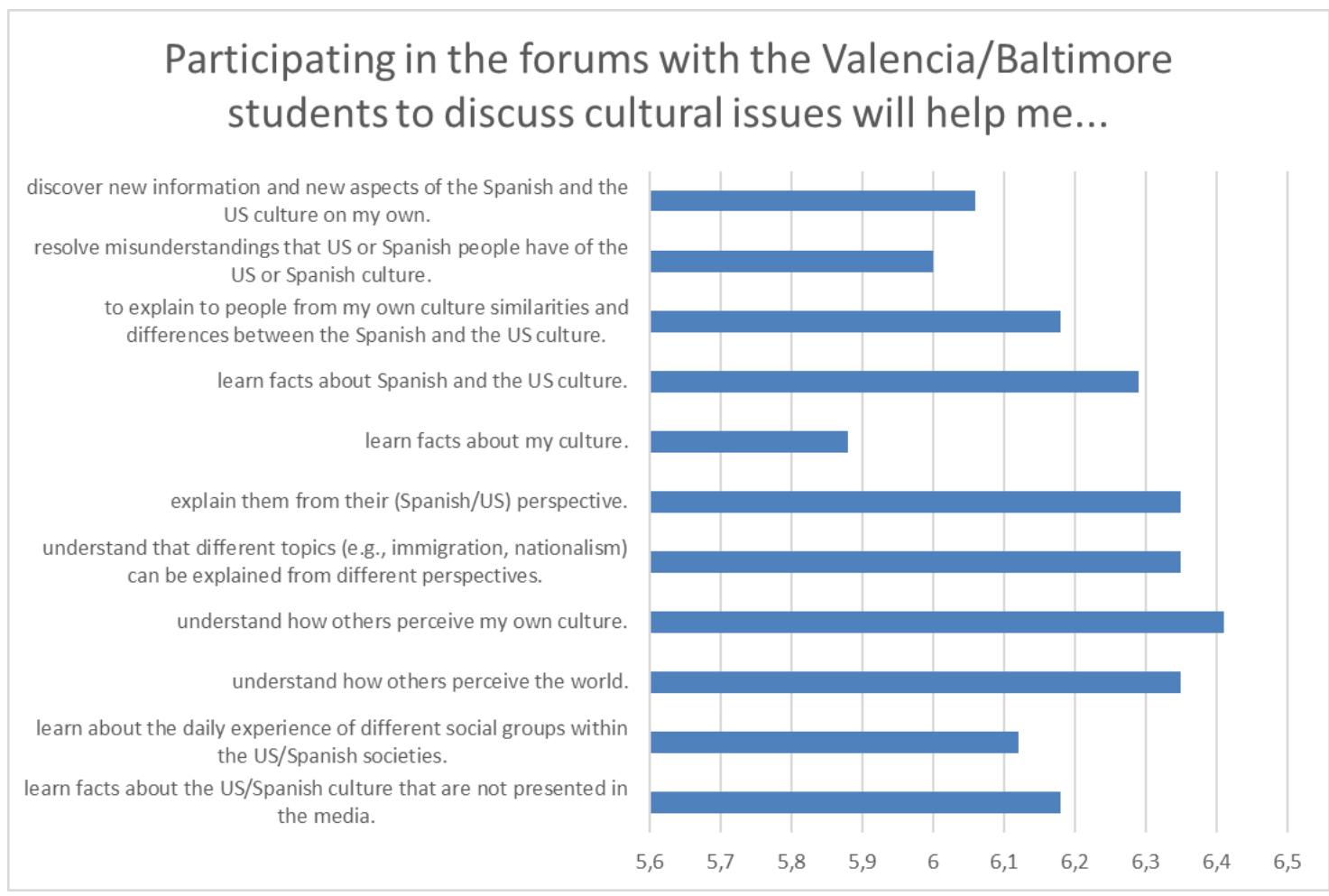

Figure 4. Attitude towards participating in the Google+ private community forum (on a 7-point scale)

Nevertheless, four major benefits stood out as being particularly valuable: 1) becoming more fully aware of how each perceived the others' culture; 2) understanding how others perceived the world; 3) providing an alternative perspective regarding the cultural issue being discussed; and 4) understanding the different topics (e.g. immigration, nationalism) can be explained from various perspectives. The least useful aspect of participating in the forums was thinking that this could help them learn facts about their own culture.

Lastly, when the students were asked about their learning expectations in producing the course artefacts, which consisted of a radiophonic podcast dealing with one of the cultural topics discussed in the online forums during the project, opinions were equally divided in two broad categories. On the one hand, some thought that creating the podcasts would help them to improve their speaking and communication skills in particular (a linguistic focus), and others thought that these would also contribute towards their understanding of cultural issues and improve their intercultural communication skills.

Post-questionnaire. The post-questionnaire was conducted after concluding the project in order to analyse student satisfaction and thus be able to correlate data with 
their expectations as reported in the pre-questionnaire. The data was collected separately by country. Therefore, in what follows, we shall compare the results specifying whether they correspond to American or Spanish students. Three quarters of the US class completed the final survey: 9 out of 12 students (75\%). Of these, 8 were female and 1 , male. In Spain, however, only 7 out of 12 students completed the questionnaire (58\%). Of these, 5 were male and 2, female.

Although the instructors gathered a wealth of data from the survey, in what follows we shall only focus on three crucial aspects. That is:

- Our learners' degree of satisfaction upon participating in an intercultural telecollaboration project and compare it with their opinion at the outset.

- Our learners' degree of satisfaction upon contributing to the cultural discussion in the ad hoc forums.

- Our learners' degree of satisfaction upon having to create a radiophonic podcast as the final course requirement.

USA: Regarding Q11 “Making a podcast for my language class was fun”, student satisfaction was reported to be greater than they had originally envisaged in the prequestionnaire. Only 1 student (11.11\%) tended to disagree, 3 (33.33\%) were neutral and over half of them $(55.55 \%)$ were happy with the experience. The following two comments are particularly clarifying, especially because the task was perceived as constituting a "low stress environment", which is obviously one of the main aims, i.e. to avoid learners feeling threatened by the telecollaboration project.

[US student \#6] Looking back, making this podcast was fun. For me, it was a great way to practice my language skills, especially because I had a helpful teacher and an awesome partner. We got to discuss current events/current themes that are important to the average college student, as well as hear other perspectives from students halfway across the world. Overall, I enjoyed the project and it held my interest from beginning to end.

[US student \#2] I thought it was a fun and low stress environment to force me to practice my spoken Spanish.

In Spain, however, 2 students were neutral (28.57\%) and the rest were highly satisfied $(71.43 \%)$. This is probably due to the fact that the Spanish students belong to a technological university were they are accustomed to using technology and subjectspecific software on a daily basis as an institutional policy. 
USA: As regards Q13 "Making a podcast was a good way to show my cultural knowledge", except for 1 student who disagreed (22.22\%) and 2 students who did not have a clear opinion on this $(22.22 \%)$, the remaining $55.55 \%$ were convinced that the task was a way of conveying what they knew about the cultural topic the podcast focused on, but they are also implicitly recognising that they had learnt new things about the L2 culture in the project and were able to put that new knowledge at the service of final task, to be assessed by their peers and/or instructor. One of the students pointed out that:

[\#6] Culturally speaking, this project was awesome. It's not too often that you're given the opportunity to build meaningful relationships with students thousands of miles away, so this was a really interesting and unique project. We got to share ideas, share values, and share cultural views with other students from Spain, and it was always interesting to compare and contrast the information/ideas as the discussions online/via Skype progressed.

Regarding the Spanish students, bar 3 who were not sure (42.86\%), the remaining $57.14 \%$ agreed that this was the case.

USA: Moving on to the learners' perception of how the telecollaboration project had helped them (Qs 24 to 32), students were asked to score 9 possible reasons. As we can see in Figure 5, in a 7-point scale, three of these clearly stood out: a) being able to interact in a real life situation with fellow university students of their own age; b) being able to meet new people who, like themselves, were studying an undergraduate degree; and c) being able to improve their intercultural communication skills. The fact that this last reason stood out together with the other two in first place was of great satisfaction to the instructors because it was naturally one of the main aims of the project itself. The two reasons that came in second place also related to a cultural aspect: a) having been able to become more closely acquainted with the L2 culture, and b) having been able to improve their cultural skills in L2. 


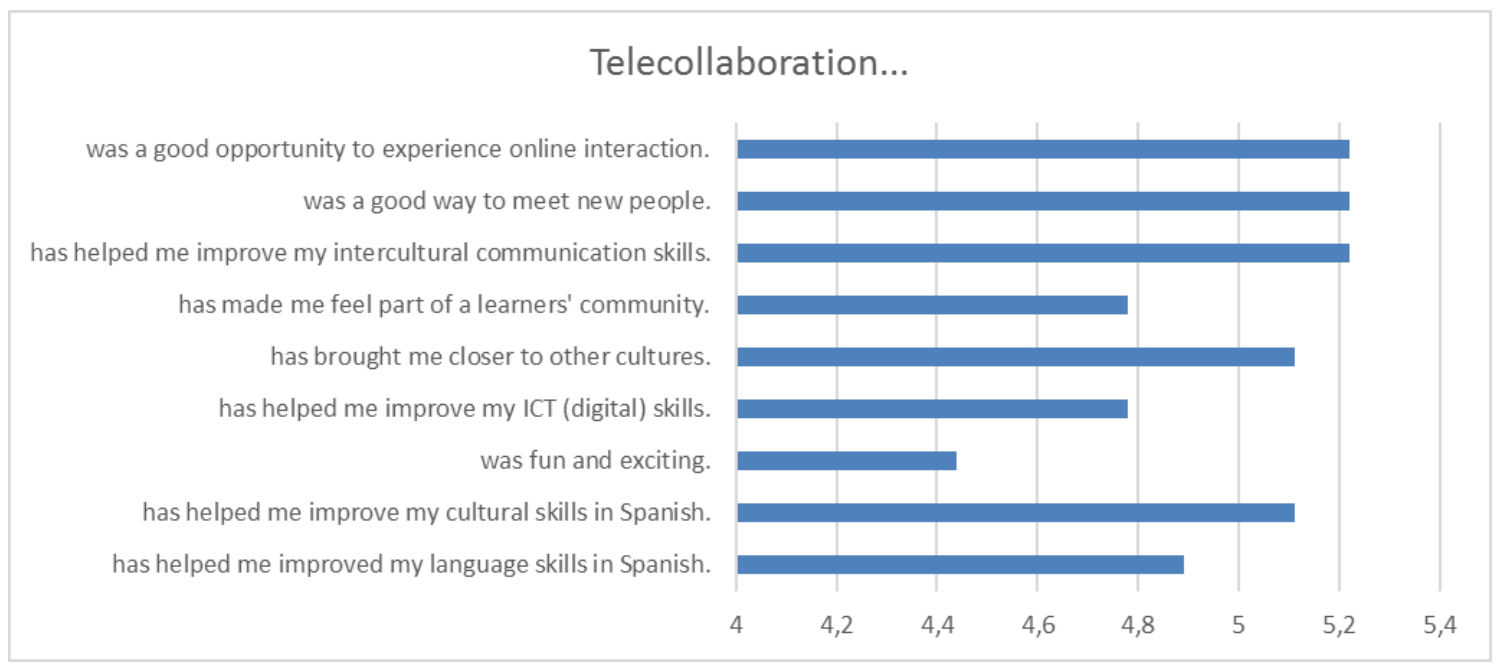

Figure 5. US students' perception in respect to how telecollaboration had helped them

Overall, the Spanish students rated all the categories higher than the US students, thus showing a slightly higher degree of satisfaction, possibly because the whole project was seen as being innovative, which led to motivation. These students highlighted the opportunity to experience online interaction with fellow learners followed in second place by three aspects: a) being able to meet new people; b) being able to improve their intercultural communication skills, both of which coincide with the US students, and c) having felt that they belonged to a community of practice (learners' community), which the US students rated lower don the scale.

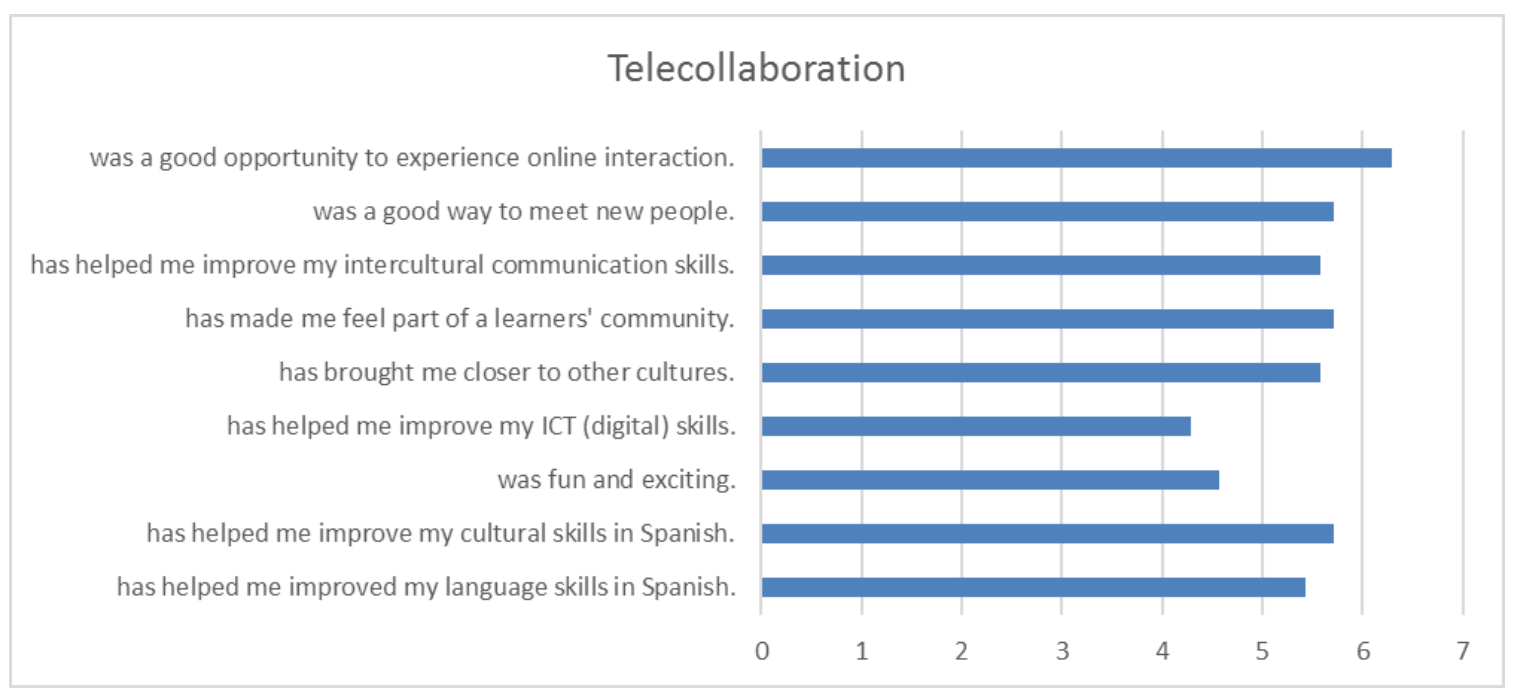

Figure 6. Spanish students' perception in respect to how telecollaboration had helped them

Whereas Spanish students thought that telecollaboration had helped them the least in improving their ICT skills (which is only natural considering their technological 
profile), their US counterparts rated telecollaboration being "fun and exciting" the lowest.

Compared with what the students believed at the outset about telecollaboration (See Figure 2), these results correlate with their initial beliefs on both sides of the Atlantic.

USA: In relation to the benefits of participating in the online forums to discuss cultural issues with their counterparts (Qs 55 to 65 ), 4 aspects primarily stood out: a) learning facts about their exchange partners' culture; b) having been given the opportunity to explain the cultural issues under debate (immigration and nationalism/patriotism) from the perspective of their own culture; c) acquiring an insight into how one's culture is perceived by others thousands of miles away; and d) having had the opportunity to learn facts about their counterparts' culture that are not presented in the media.

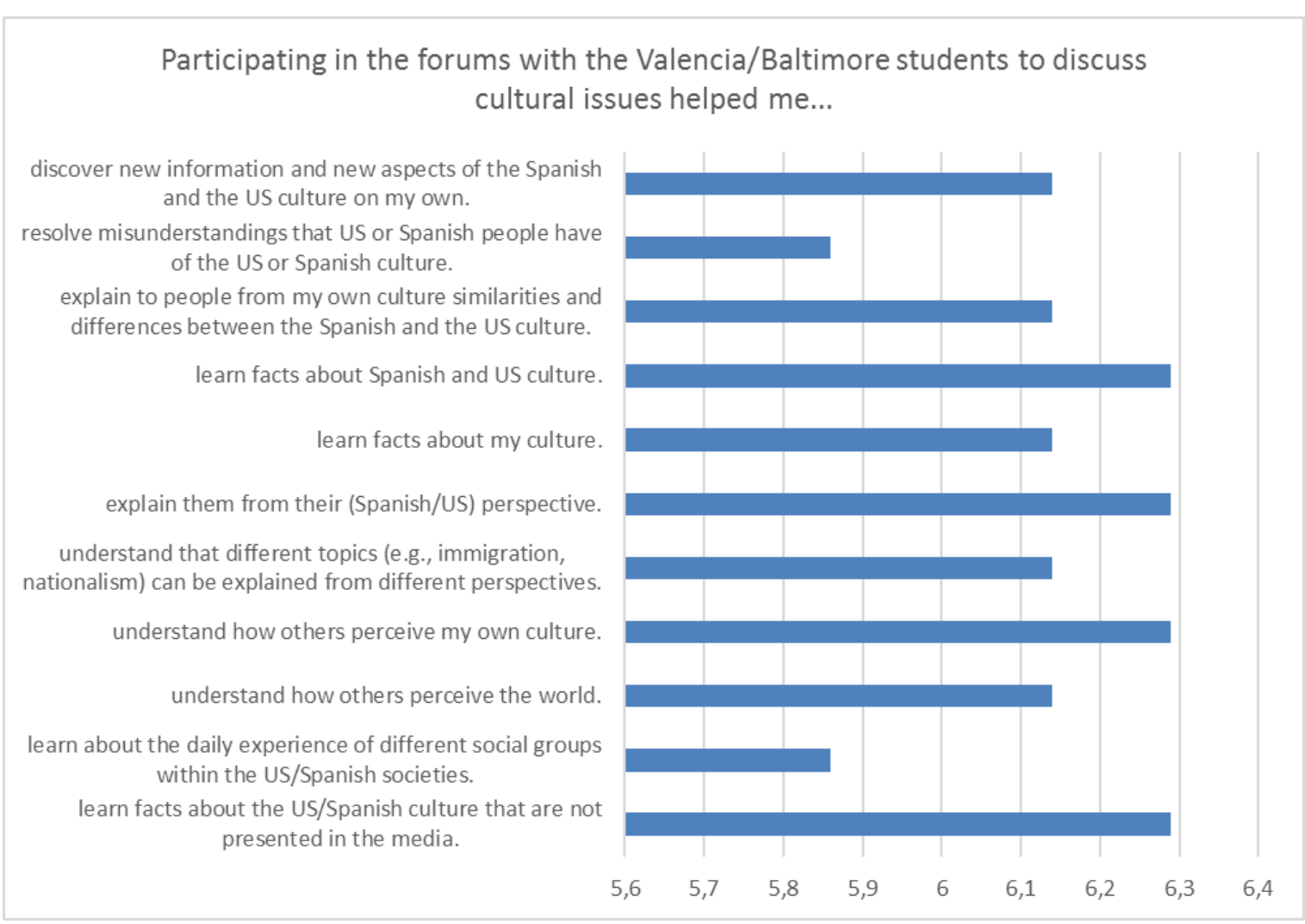

Figure 7. US students' perceived benefits of participating in the online forums (7-point scale).

Like the US students, the Spanish students also perceived that participating in the forums had helped them understand how others perceive one's own culture but 
differed in other aspects. In particular, they pointed out the that forums had helped them discover new information and new aspects about the L2 culture on their own (which implies that, in order to discuss a specific cultural issue pertaining to the L2 culture, they had to investigate the topic and gather relevant information that would allow them to contribute meaningfully to the forum discussions), and also that a given topic can be explained from different perspectives, a fact that no doubt contributes toward becoming more open-minded and tolerant with opposing opinions. Additionally, this last benefit was not foreseen to such a great extent by the students in the pre-questionnaire.

Overall, though, the results derived from the pre-questionnaire correlate to those from the post-questionnaire, which leads us to believe that, in most cases, the leaners were able to foresee how participating in the online discussions would help them in terms of "interculturality".

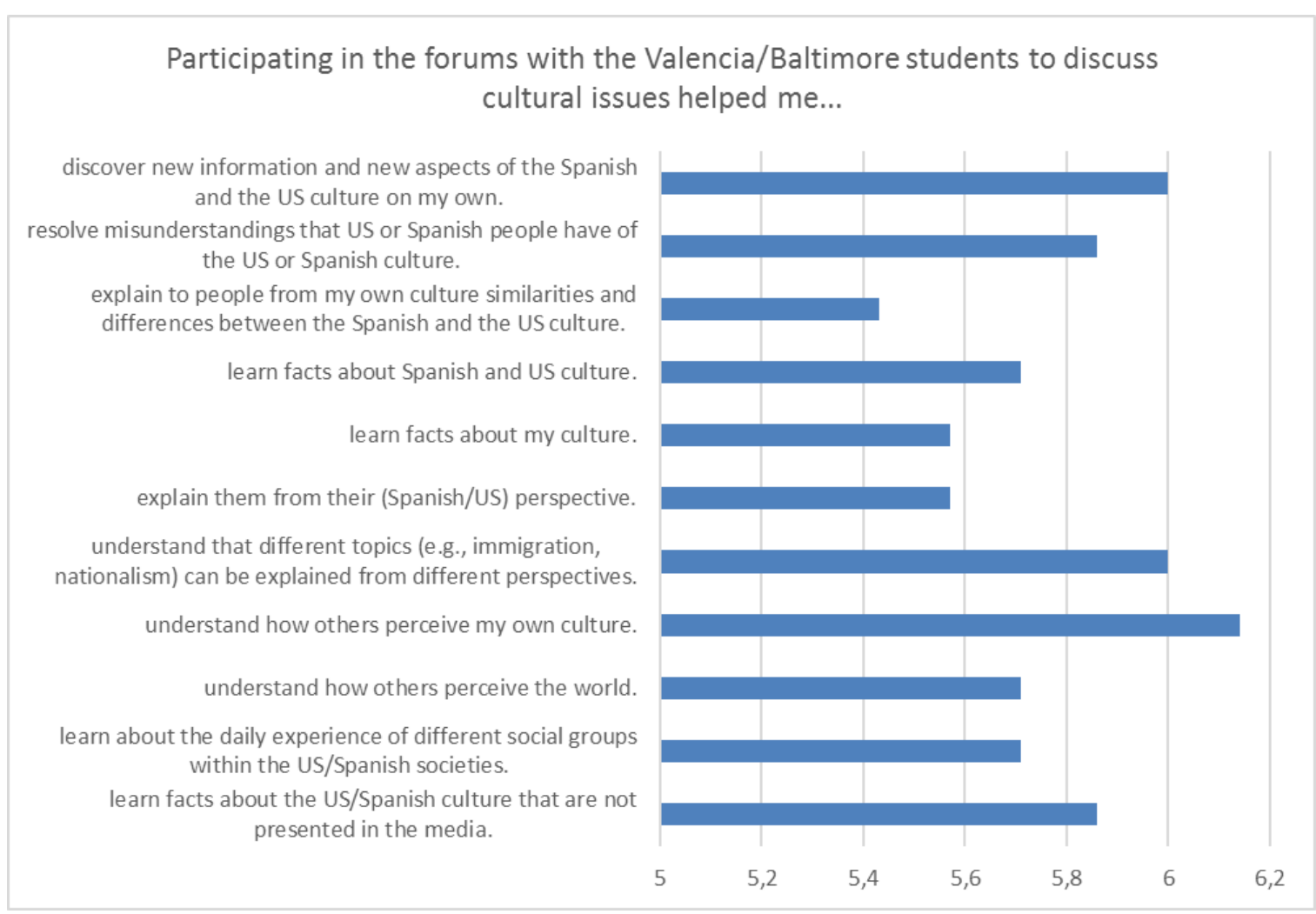

Figure 8. Spanish students' perceived benefits of participating in the online forums (7-point scale)

The students were also requested to define what they knew about immigration trends (why and how immigrants move across countries) in relation to the US and Spanish (Q66). Despite the fact that their answers did not vary substantially to that reported in 
the pre-questionnaire. However, the following response illustrates how a learner acknowledges having gained a closer understanding of immigration trends in Spain.

[US student \# 2] My knowledge of immigration with respect to the US has not changed. However, I did not expect to see such a complex immigration pattern with respect to Spain. Now I know that there is a large flux of educated youth out of Spain and into other European countries after the economic crisis in 2008 in addition to the influx of people from Latin American countries into Spain.

USA and Spain: The instructors also queried about (Q67) the students' knowledge about the concept of 'nationalism' in relation to the US and Spain. Most of them pointed out that it was more prominent in the US. The following statement sums up why they reached this conclusion:

[US student \#6] National values and nationalism play a huge role in American life. Although every American has a state that they call home, the majority refer to themselves first and foremost as "American." In contrast, Spanish culture doesn't have that same positive attitude towards nationalism. Spaniards usually identify themselves based upon the autonomous community/region in which they come from (Basque Country, Catalunya, Andalusia, etc) rather than identifying themselves as a "Spaniard."

Regarding the type of activity the learners thought was most useful (Q70), it was interesting to see how the learners differed according to country. The American students (Figure 9) by far preferred the online written discussions conducted through the Google + private community $(100 \%)$ - that, is interacting with their counterparts and exchanging viewpoints and opinions regarding the topics under discussion-whereas, as we can see in Figure 10, the Spanish learners preferred taking part in and watching the sound-enhanced Powepoint presentations (71.43\%) that all the students had to prepare (per university, per group) and deliver after each of the discussion topics had come to an end. That is, the Spanish students watched and discussed in class both the American students' presentations as well as their fellow Spanish classmates' presentations. This proved particularly interesting from the learners' point of view and successful from the instructors' point of view because the activity made them aware how their counterparts had truly incorporated information provided not only from their own research but also from their fellow international "informants" - thus rewarding them with a feeling of having been "useful" and contributing toward the others' learning process. 


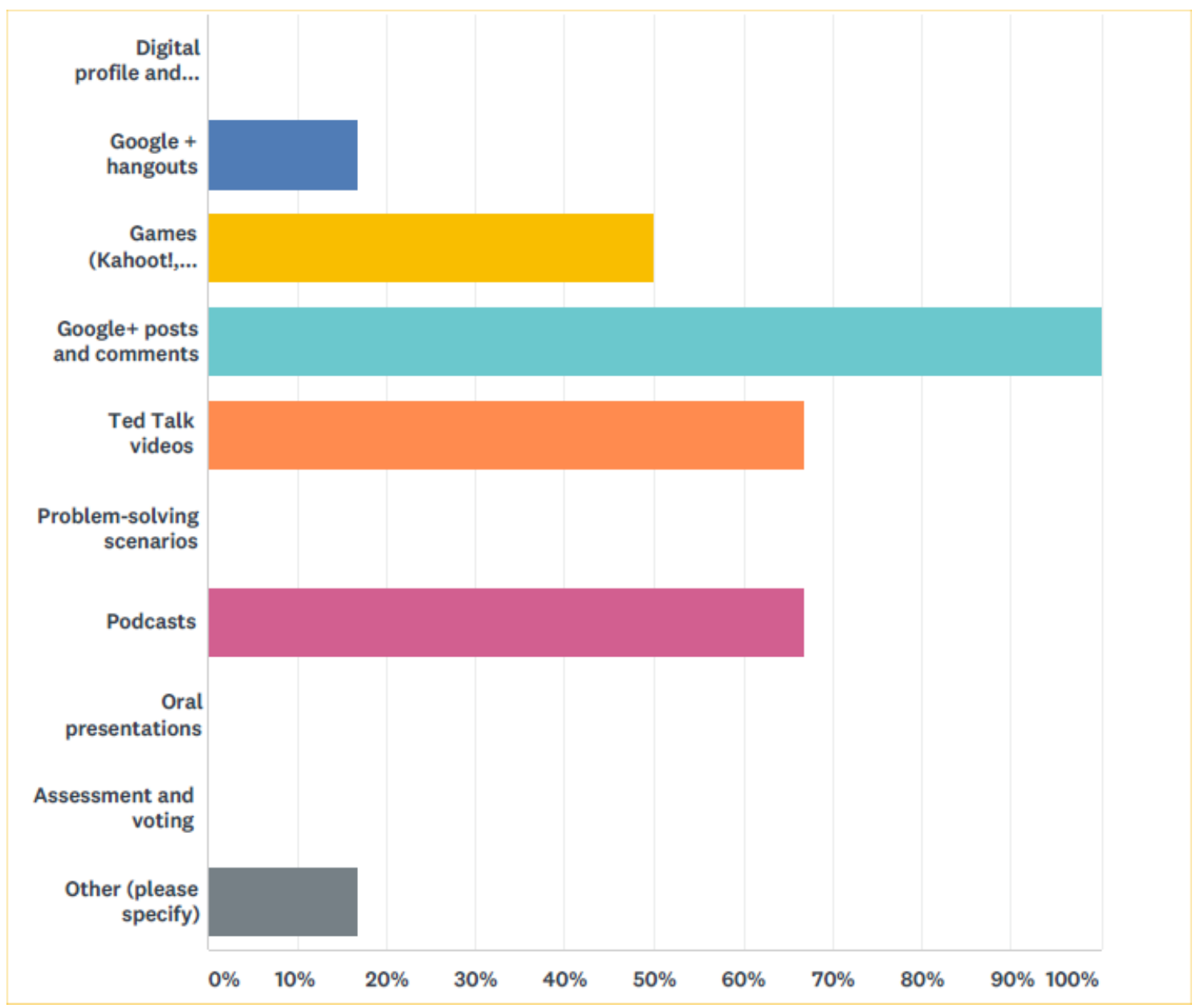

Figure 9. US student's perception of what the most useful activity was in the project

In second place the Spanish students preferred the Kahoot quizzes (57.14\%) because they enjoyed the gamification component and competing with their class mates and, in third place, came the "face-to-face" synchronous interaction conducted via Skype (42,86\%). Whilst the US students conducted this activity in class, due to the 6hour time difference, the Spanish students conducted the activity late in the evening from their homes, which was an added hurdle that they were, however, happy to overcome. 


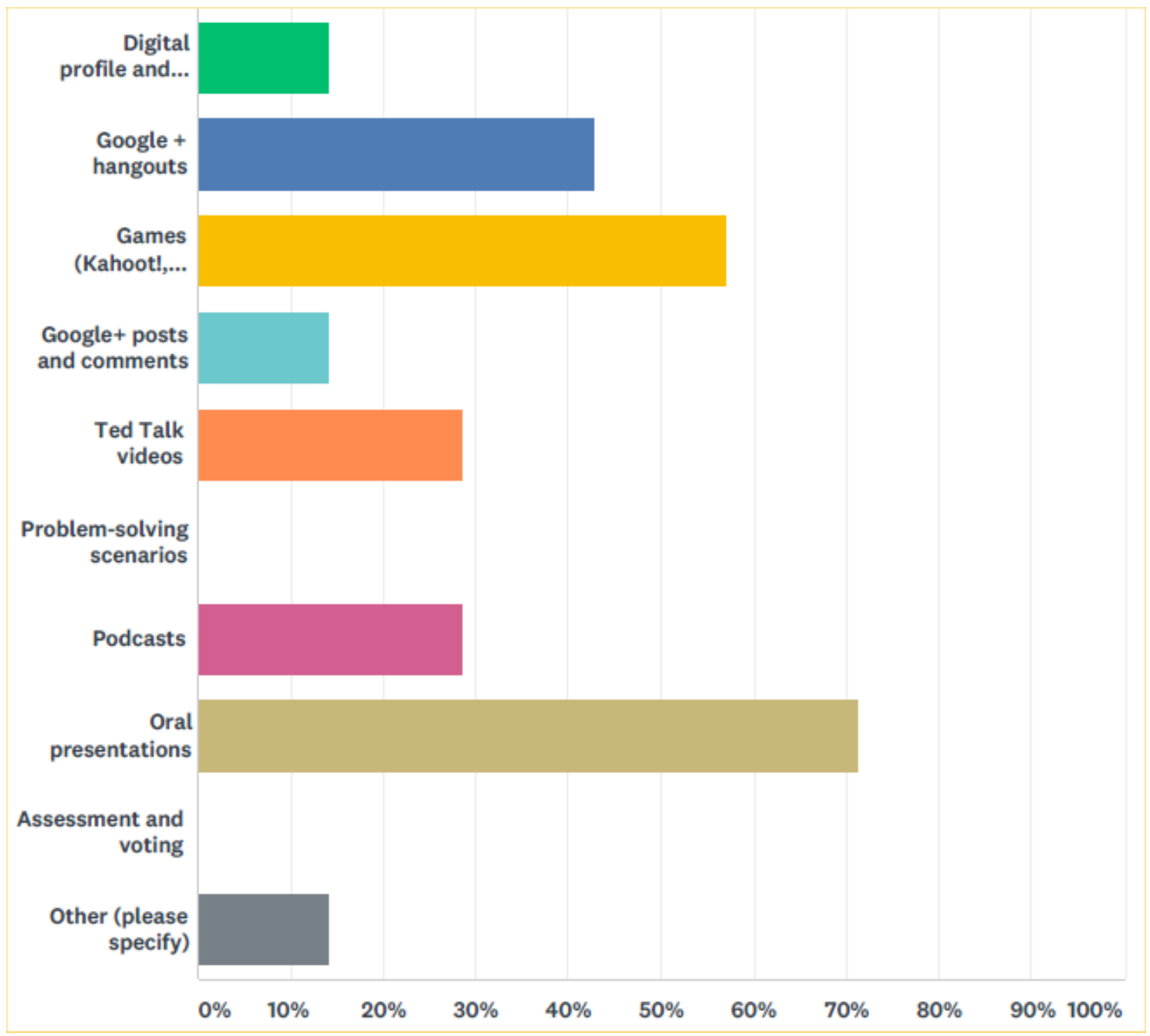

Figure 10. Spanish student's perception of what the most useful activity was in the project

Another interesting finding resulted from asking students to write down in one minute as many things as they could about their telecollaboration partners' country and culture (Q71) and the follow-up question inquiring about how they had obtained that information (Q72). Interestingly, students coincide in their responses; $100 \%$ of them both in the US and Spain- report that their "foreign partners" had told them (Figures 11 $\& 12$ ). This reinforces the idea that, at the outset, the students took the task of becoming informants for their counterparts very seriously, which was one of the main aims of the project, i.e. encouraging students to take responsibility over the learning process and provide both appropriate channels where reliable information could be sought and offer their own viewpoints.

However, the other responses differed considerably. The US students reported that their teacher had been an important source of information $(83.83 \%)$ and also that 
they had acquired knowledge "through the telecollaboration tasks" (83.83\%). Spanish students, on the other hand, felt equally (28.57\%) about: a) Through the Kahoot! Game; b) Googling for information, and c) Through the telecollaboration tasks.

A factor that differed between learners on either side of the Atlantic was that, in the States, culture and history were core to the subject whereas in the Spanish context, despite the telecollaboration project being an integral part of the subject, it was an addon and so students did not receive additional tuition in these areas, which is the reason why only 1 person (14.29\%) reported learning about their counterparts' country from their instructor.

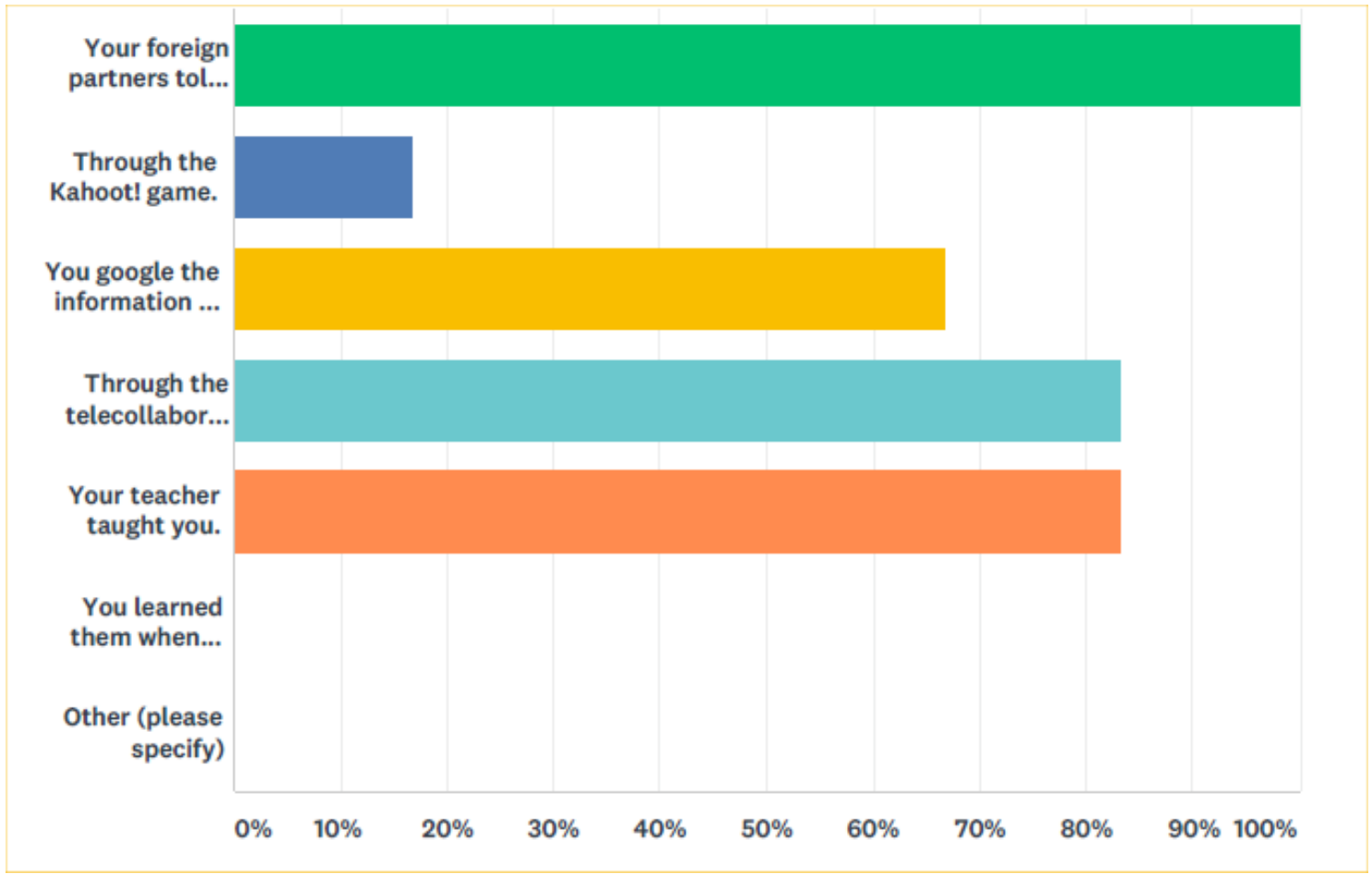

Figure 11. The channels through which US students perceived that they had gained new information 


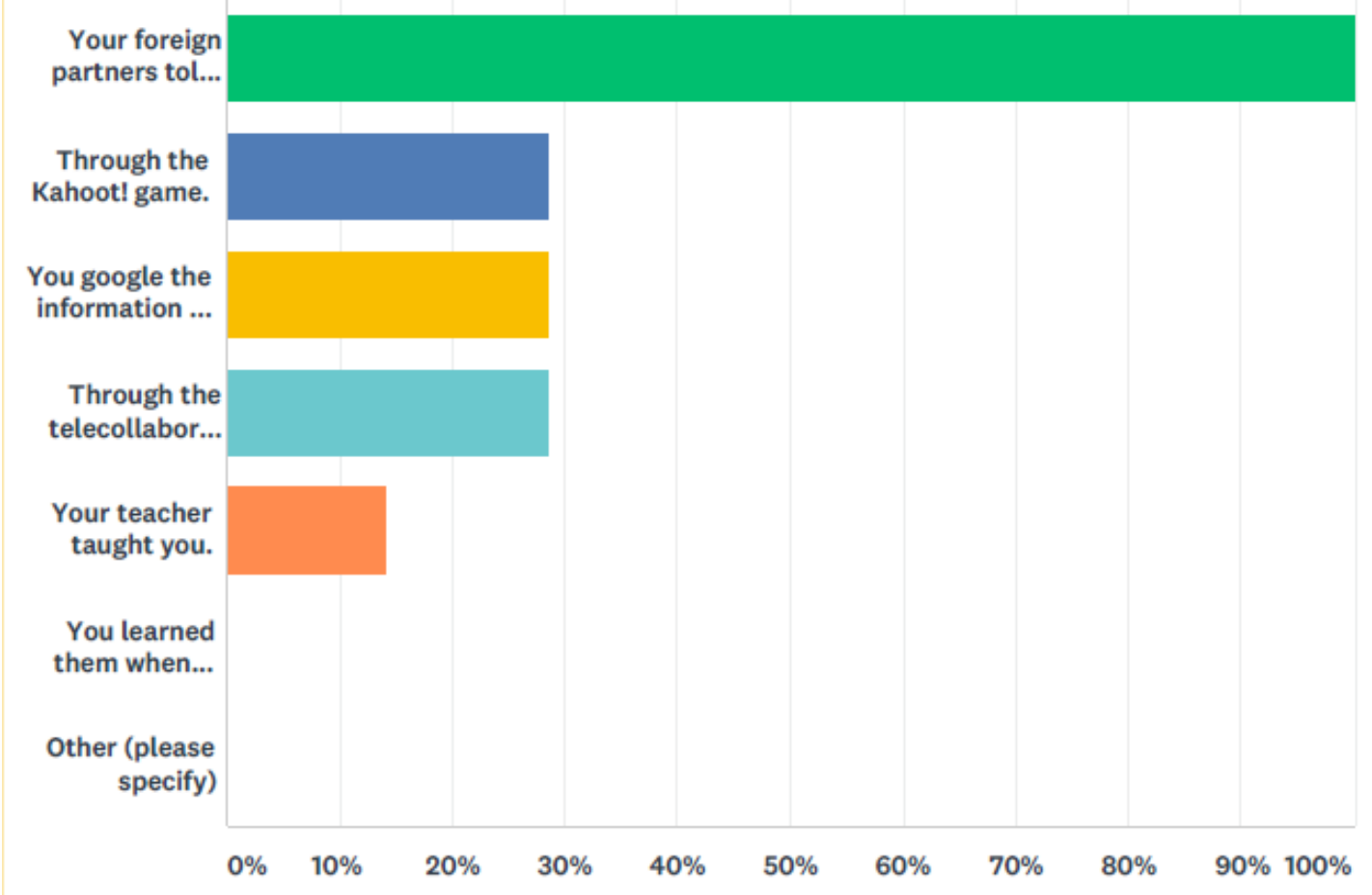

Figure 12. The channels through which Spanish students perceived that they had gained new information

When the students were asked what they thought about the telecollaboration experience (Q73), all of the US students thought it was interesting (100\%), however the Spanish students found it equally fun, useful, and interesting (57.14\%), albeit to a lesser extent. 


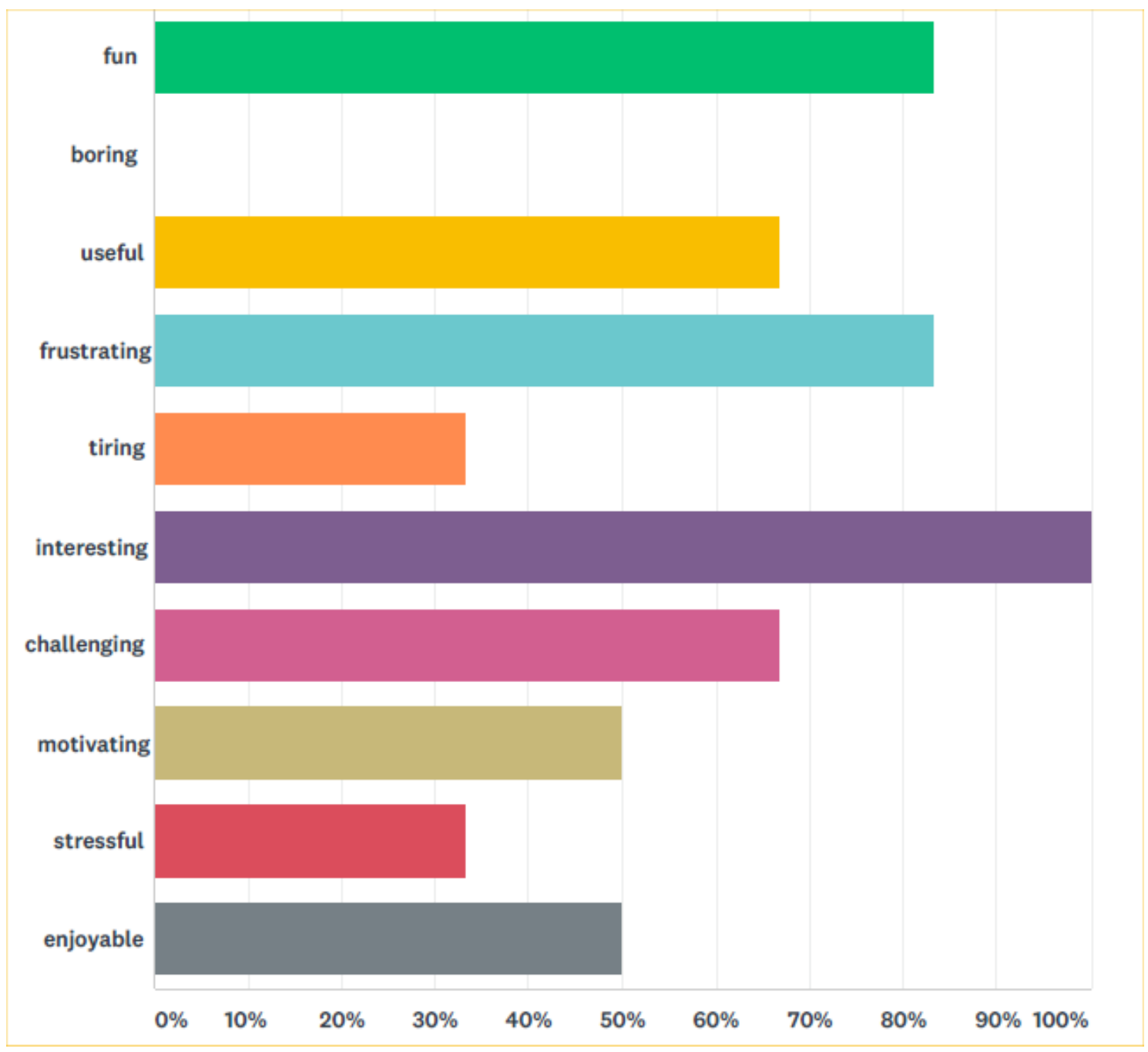

Figure 13. US students' opinion about the telecollaboration project

Interestingly, though, American students reported being somewhat frustrated by the experience, whereas none of the UPV students even remotely felt this $(0 \%)$. This could be due to the fact that, although part of their final grade was dependant on their performance on the project tasks, they saw it as an "interesting" and "useful" add-on to their English class and readily welcomed the idea of the exchange project.

Another notable difference was the fact that $66.67 \%$ of the US students reported they found the entire process challenging, whereas none $(0 \%)$ of the UPV students had this feeling, and a third of the US students (33.33\%) found the project stressful, whereas UPV students did not (0\%). 


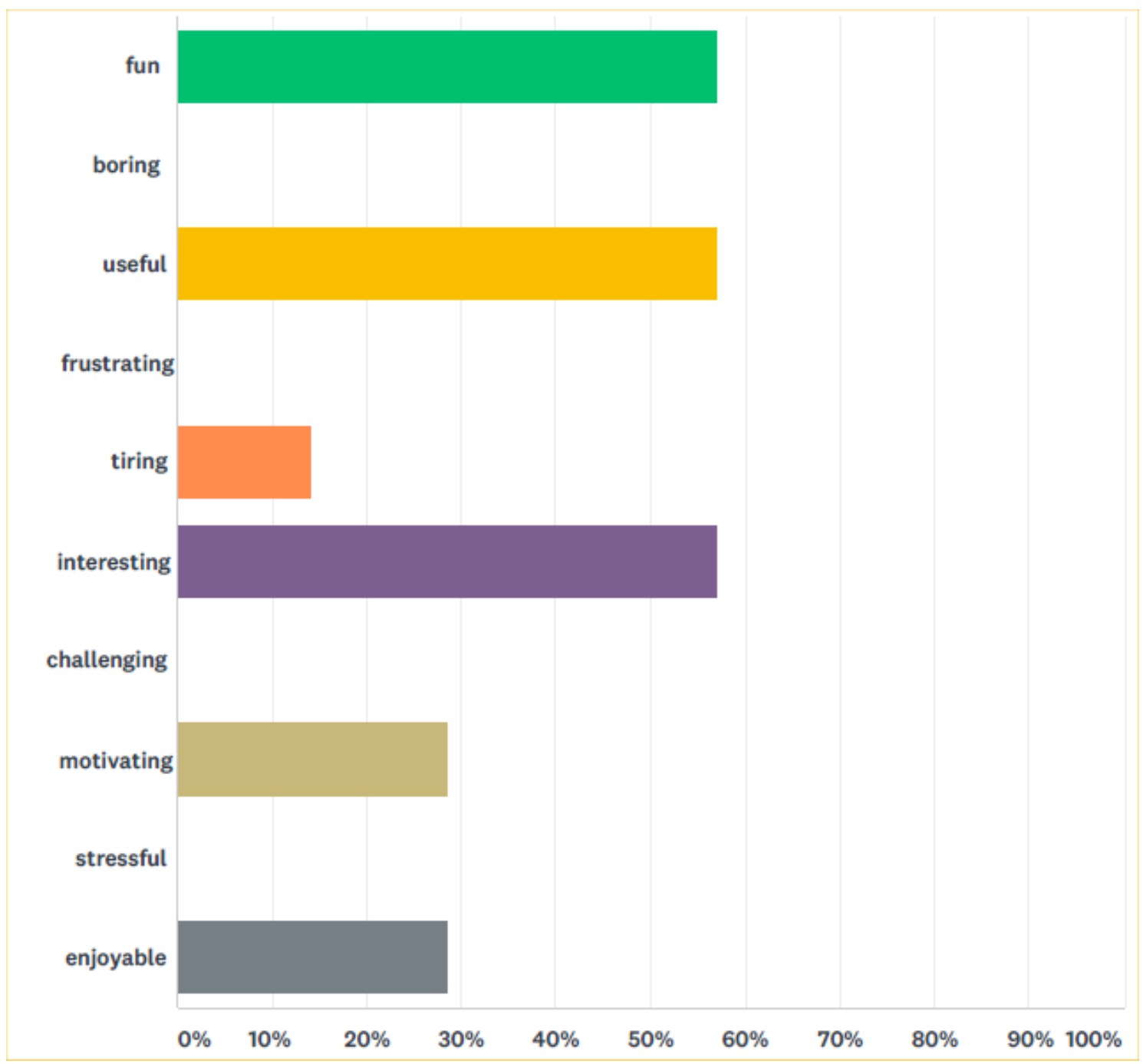

Figure 14. Spanish students' opinion about the telecollaboration project

When we asked our learners how the telecollaboration project had contributed toward the development of certain skills (Q75), they reported the following, as displayed in Figures 15 and 16. On the one hand, the US students highlighted that the project had first and foremost helped them develop their team-working skills (83.33\%), whilst vocabulary, speaking, reading, writing, critical thing and research skills all scored $66.67 \%$, placing them in second place.

However, in Spain, the students thought that the project had helped them improve a) their listening skills (85.71\%) -thus placing more emphasis on the linguistic side of the learning process-; followed by b) vocabulary and speaking skills alike $(71.43 \%)$; c) reading skills $(57.14 \%)$, and d) writing skills, creativity, critical thinking, research skills and team-working skills. 


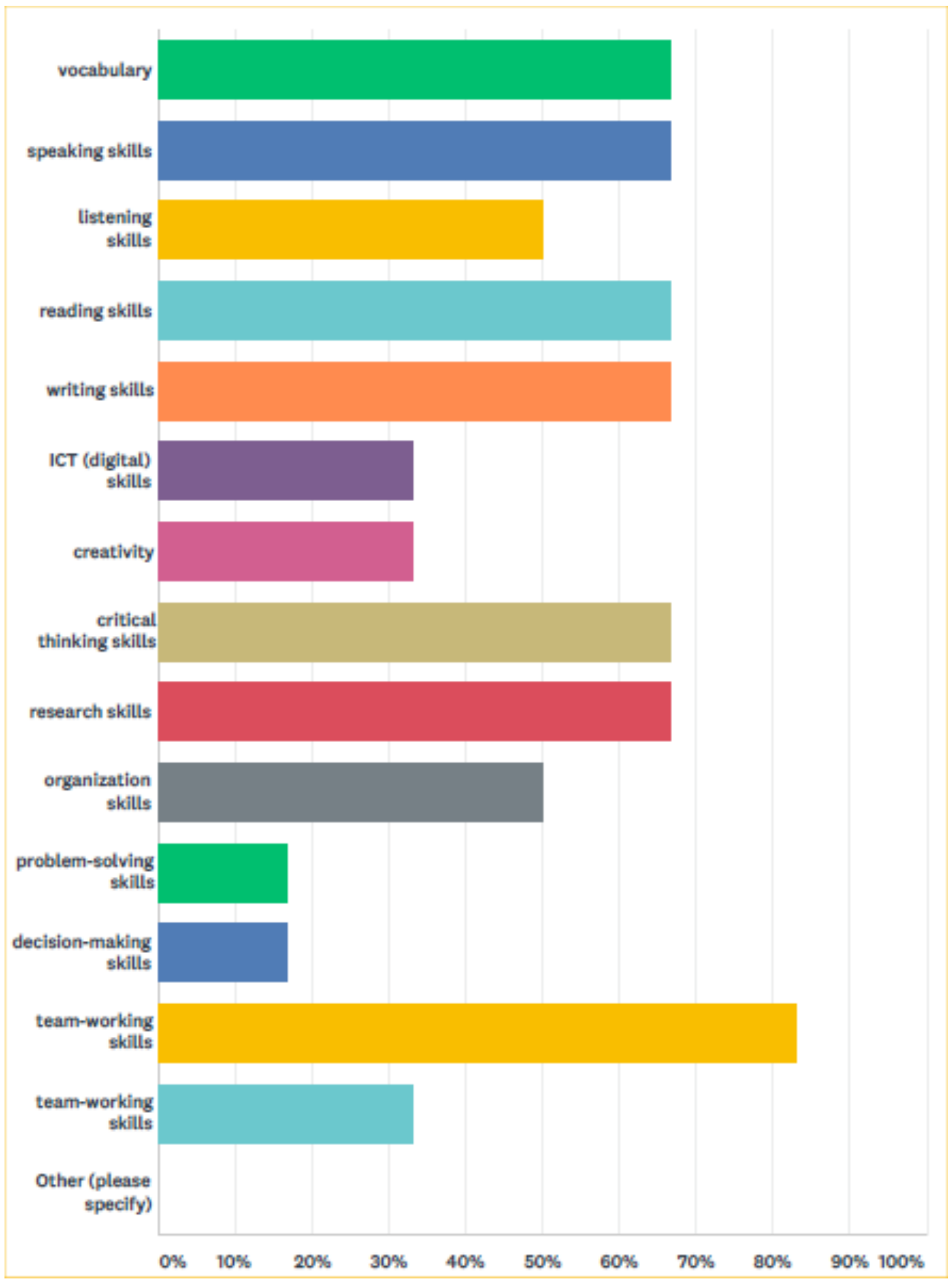

Figure 15. US students' perception of how the project had helped them develop certain skills 


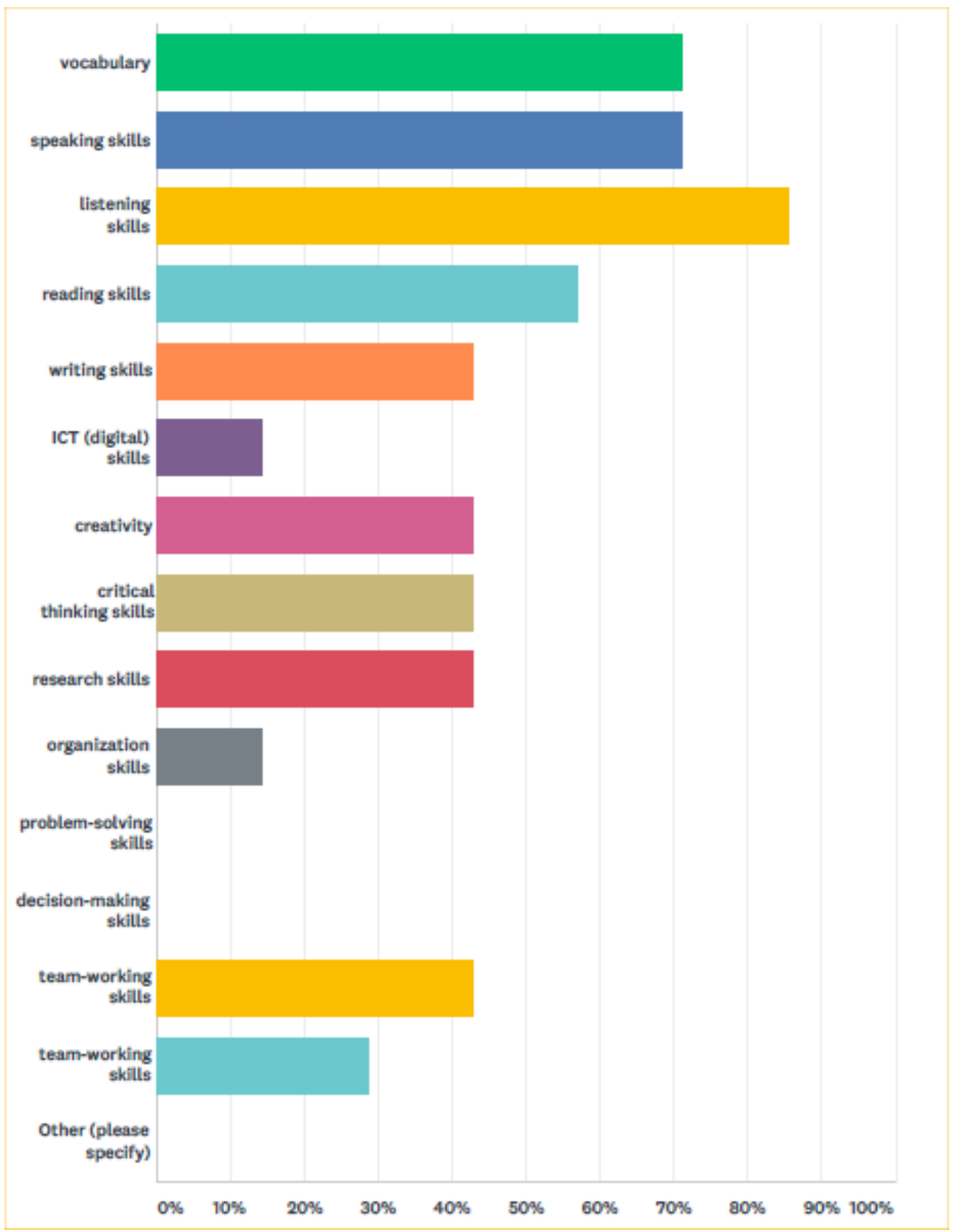

Figure 16. Spanish students' perception of how the project had helped them develop certain skills

Lastly, they were asked to identify something that they had particularly liked (Q78) and something that they had disliked (Q79). The following are the open text answers that were reported: 


\section{US students LIKED}

- Getting to learn so much not only about your own country but also about Spain as well as hearing their opinions on things in the US.

- We were able to compare and contrast the ideas of other students and that there were opportunities for a lot of group interaction.

- Getting to learn first hand from other students. It's not like learning from a textbook - it's so interesting to talk to people your own age, share your experiences, and teach each other about your own personal culture.

- Learning about the perspectives of others.

- The exposure to another culture and having honest thoughts from outsiders looking in on our culture.

- Getting to know our partners. It was interesting to learn about their lives and life overseas.

\section{UPV students LIKED}

- The Skype sessions.

- The possibility of exchanging information with people from another continent.

- The test game.

- The people I met.

- The Skype calls.

- Learn about the culture of the United States.

We interpret that the students enjoyed the Skype sessions because these enabled them to see each other and interact in real time with their fellow American group members and subsequently, as reported in the pre-questionnaire, satisfy one of their expectations, which was the chance to meet new people.

Regarding what they disliked, this is what each of them wrote:

\section{US students DISLIKED}

- The Skype sessions only worked for 2 of the times and sometimes people did not post on time.

- The students from Spain did not participate as much as was needed, which hindered some of the tasks. 
- It was a bit hard to have consistent contact with our Spanish friends, and it was hard to ensure that we were all putting the same amount of effort into the project.

- The Spaniards were difficult to get in contact with.

- The fact that it was worth like 35\% of my final grade!!!!!!!!!!!!!!!!!!!!!!!! For a first time project that has a lot of kinks to work out, that is bull shit. I did end up enjoying it, and it got better as the semester went along in terms of more equal participation, but with that said, I still don't think that this grade should've been anything more than a little participation grade.

\section{UPV students DISLIKED}

- Some topics (nationalism).

- The difficulties for meeting them with skype.

- The skype meetings were always set at 9pm and I always had class so I couldn't attend all of them.

- $\quad$ The deadlines.

- Write such long comments for the different topics we have discussed.

As we can see, UVP students were also frustrated with the difficulties caused by the different time zones for which reason they had to communicate with their US group members late in the evening, as well as having to overcome a number of technical glitches.

Another notable "complaint" on behalf of UPV students was that they claimed that their American counterparts were far more prolific in their online forum discussions, while, as is customary in scientific disciplines such as Aerospace Engineering, UPV learners were far more concise and direct to the point in their online written exchanges (comments derived from class activity with the instructor).

To conclude, students were requested to write what their overall opinion of the telecollaboration project was $(\mathrm{Q} 80)$. These are their personal statements:

\section{US students}

- Helpful and interesting in that you get to hear from other people as well as practice your language skills but that there were some technical bumps in the road along the way. Overall it was a beneficial project that just had a few kinks. 
- I think it can be very effective and a great thing to incorporate in the classroom as long as their is equal participation.

- I really did enjoy this project. I wish that it could've been a separate class from the Spanish history class itself, but I know that's not a possibility at UMBC. I learned a lot, and the project made me really interested not only in Spain, but in history, of any culture/country.

- Interesting but needs to be more structured on both sides.

- That is a useful way to connect young people from different cultural backgrounds. It fosters genuine concern for people outside of your immediate bubble. It promotes caring about more global affairs.

- I think it has serious potential, if you find a better platform and ensure that everyone has the same expectations/understandings in terms of workload. Otherwise, just stick to the textbook!

\section{UPV students}

- It's a good way to learn English.

- That it can be very helpful.

- 10 out of 10

- It's a good experience to meet people and get to know other cultures.

- It was an interesting project to do but it was tiring sometimes and I think it could be more interesting with other topics.

- A very good experience to see what is out there, and learn from what's not within our local range.

- It is a good way to be able to meet people from other countries (and in turn from other cultures), and with which to practice the native language of them.

\section{Conclusions}

After conducting telecollaborative encounters during one semester between North American and Spanish students in which intercultural communication was at the heart of the project, the researchers were able to find evidence, through the pre and post project questionnaires administered, that verified what was only an intuition at the outset. The surveys highlighted the fact that the students on both sides of the Atlantic were highly motivated foreign language learners and had high expectations toward the 
project. They were very open minded about discussing multifaceted intercultural issues and very positive toward collaborating with fellow students from a different cultural background. They were all in favour of using Information and Communications Technologies (ICT) for language learning purposes and did not interpret communicating in writing through the Google+ community nor orally through Skype as hindering authentic intercultural communication and interaction. The surveys also provided evidence that the learners' expected benefits correlated with their stated benefits after carrying out the project, which led us to believe that possible frustrations and communication breakdowns had been kept to a minimum. Regarding specific gains, there was clear evidence that UPV students, in particular, saw the project as being beneficial for their EFL improvement, which was also one of the project aims. There was, however, a noticeable conflict in terms of the differences in the educational systems; i.e. the students in each of the two countries involved belonged to two very distinct educational contexts (aerospace engineering versus completing a major or minor in Spanish) which strongly determined the students' academic expectations and these were, in turn, transferred to the telecollaborative environment.

\section{References}

Adichie, C. (2009). The danger of a Single Story. Retrieved from http://www.ted.com/talks/chimamanda_adichie the_danger_of_a single_story.

Arnold, N., \& Ducate, L. (2006). Future language teachers' social and cognitive collaboration in an online environment. Language Learning \& Technology, $10(1), 42-63$.

Basharina, O. K. (2007). An activity theory perspective on student-report contradictions in international telecollaboration. Language Learning \& Technology, 11(2), 82103.

Bauer, B., de Benedette, L., Furstenberg, G., Levet, S., \& Waryn, S. (2006). The Cultura project. In J. A. Belz \& S. L. Thorne (Eds.), Internet-mediated intercultural FL education (pp. 31-62). Boston: Heinle \& Heinle.

Belz, J. A. (2003). Linguistic perspectives on the development of intercultural competence in telecollaboration. Language Learning \& Technology, 7(2), 6899. 
Chandrasegaran, A., \& Kong, K.M. (2006). Stance-taking and stance-support in students' online forum discussion. Linguistics and Education, 17, 374-390.

Chun, D. (2011). Developing intercultural communicative competence through online exchanges. CALICO Journal, 28(2), 392-419.

Depalma, R. (2010). Toward a practice of polyphonic dialogue in multicultural teacher education. Curriculum Inquiry, 40(3), 436-453. DOI: http://doi.org/10.1111/j.1467-873X.2010.00492.x

Elola, I., \& Oskoz, A. (2008). Blogging: Fostering intercultural competence development in foreign language and study abroad contexts. Foreign Language Annals, 41(3), 421-444.

Freire, P. (1970). The pedagogy of the oppressed. London: Penguin.

Fuchs, C., Snyder, B., Tung, B., Jung, Y., \& Snyder, H. (2017). The multiple roles of the task design mediator in telecollaboration. ReCALL, 29(3), 239-256. DOI: http://doi.org/10.1017/S0958344017000088

Guth, S., \& Helm, F. (2010). Telecollaboration 2.0: Language, literacies and intercultural learning in the 21st century. New York: Peter Lang Publishers.

Guth, S., \& Marini-Maio, N. (2010). Close encounters of a new kind: The use of Skype and Wiki in telecollaboration. In S. Guth \& F. Helm (Eds.), Telecollaboration 2.0: Language, literacy and intercultural learning in the 21st century (pp. 413426). Bern: Peter Lang.

Guth, S. \& Thomas, M. (2010). Telecollaboration with Web 2.0 Tools. In S. Guth \& F. Helm (Eds.), Telecollaboration 2.0: Language, literacy and intercultural learning in the 21st century (pp. 39-68). Bern: Peter Lang.

Hauck, M., \& Youngs, B. L. (2008). Telecollaboration in multimodal environments: The impact on task design and learner interaction. Journal of Computer Assisted Language Learning, 21(2), 87-124. DOI: http://doi.org/10.1080/09588220801943510

Helm, F. (2013). A dialogic model for telecollaboration. Bellaterra Journal of Teaching \& Learning Language \& Literature, 6(2), 28-48. DOI: http://doi.org/10.5565/rev/jt13.522

Helm, F. (2016). Facilitated dialogue in online intercultural exchange. In T.L.R. O’Dowd (Ed.), Online intercultural exchange: Policy, pedagogy, practice (pp. 150-172). New York/London: Routledge. 
Kern, R., Ware, P., \& Warschauer, M. (2004). Crossing frontiers: New directions in online pedagogy and research. Annual Review of Applied Linguistics, 24, 243260.

Kohn, K., \& Hoffstaedter, P. (2017). Learner agency and non-native speaker identity in pedagogical lingua franca conversations: Insights from intercultural telecollaboration in foreign language education. Computer Assisted Language Learning, 30(5), 351-367. DOI: http://doi.org/10.1080/09588221.2017.1304966

Lee, L. (2009). Promoting intercultural exchanges with blogs and podcasting: A study of Spanish-American telecollaboration. Computer Assisted Language Learning, $22(5), 425-443$.

Lee, L. (2010). Exploring wiki-media collaborative writing: A case study in an elementary Spanish Course. CALICO Journal, 27(2), 260-276.

Lee, L. (2011). Blogging: Promoting learner autonomy and intercultural competence through study abroad. Language Learning \& Technology, 15(3), 87-109.

Liaw, M., \& Master, S. B. (2010). Understanding telecollaboration through an analysis of intercultural discourse. Computer Assisted Language Learning, 23(1), 21-40. DOI: http://doi.org/10.1080/09588220903467301

Müller-Hartmann, A. (2006). Learning How to Teach Intercultural Communicative Competence via Telecollaboration: A Model for Language Teacher Education. In J. A. Belz \& S. Thorne (Eds.), Internet-mediated intercultural foreign language education (pp. 63-84). Boston: Heinle \& Heinle.

O'Dowd, R. (2007). Evaluating the outcomes of online intercultural exchange. ELT Journal, 61(2), 144-153. DOI: http://doi.org/10.1093/elt/ccm007

O'Dowd, R. (2016). Emerging Trends and New Directions in Telecollaborative Learning. CALICO Journal, 33(3), 291-310. DOI: http://doi.org/10.1558/cj.v33i3.30747

O'Dowd, R., \& Ritter, M. (2006). Understanding and working with "failed communication" in telecollaborative exchanges. CALICO Journal, 23(3), 623642.

O'Rourke, B. (2007). Models of telecollaboration (1): E(tandem). In R. O'Dowd (Ed.), Online intercultural exchange: An introduction for foreign language teachers (pp. 41-62). Clevedon, UK: Multilingual Matters. 
Oskoz, A. (2009). The Use of Online Forums to Integrate the Standards into the Foreign Language Curriculum. In V. Scott (Ed.), Principles and practices of the standards in college foreign language education. (pp. 106-125). Boston, MA: Heinle \& Heinle.

Oskoz, A. (2012). Developing a Community of Inquiry in a Foreign Language Blended Course. In Z. Akyol \& R. Garrison (Eds.), Educational communities of inquiry: Theoretical framework, research and practice (pp. 267-294). Hershey, PA: IGI Global.

Oskoz, A., Gimeno, A. \& Sevilla, A. (2018). Chapter 8. Examining L2 Learners' Use of Engagement Strategies in Telecollaborative Written Interactions. In B. Mousten, S. Vandepitte, E. Arnó \& B. Maylath (Eds.), Cooperation on multilingual writing in global virtual learning environments. Hershey, PA: IGI-Global.

Oskoz, A., \& Pérez-Broncano, O. (2016). What did you say? How did you say it? Linguistic choices in online discussions. Foreign Language Annals, 49(4), 772788.

Sevilla-Pavón, A., \& Haba Osca, J. (2016). “Te das cuenta de que el mundo puede ser tan distinto y similar al mismo tiempo": Telecolaboración y desarrollo de la competencia intercultural en la educación superior. Didáctica. Lengua y Literatura, 28, 263-284. DOI:1 http://doi.org/0.5209/DIDA.54088

Schneider, J., \& von der Emde, S. (2006). Conflicts in cyberspace: From Communication breakdown to intercultural dialogue in online collaborations. In J. A. Belz \& S. Thorne (Eds.), Internet-mediated intercultural foreign language education (pp. 178-206). Boston: Heinle \& Heinle.

Turula, A. (2017). Teaching presence in telecollaboration: Keeping an open mind. System, 64, 2133. DOI: http://doi.org/10.1016/j.system.2016.12.001

Ware, P.D., \& Kramsch, C. (2005). Toward an Intercultural stance: Teaching German and English through collaboration. Modern Language Journal, 89(2), 190-205.

Ware, P.D., \& O’Dowd, R. (2008). Peer feedback on language form in telecollaboration. Language Learning \& Technology, 12(1), 43-63.

Weasenforth, D., Biesenbach-Lucas, S., \& Meloni, C. (2002). Realizing constructivist objectives through collaborative technologies: Threaded discussions. Language Learning \& Technology, 6(3), 58-86. 
Wertsch, J.V. (1991). Voices of the mind: A sociocultural approach to mediated action. Cambridge, MA: Harvard University Press.

Wertsch, J.V. (1998). Mind as action. New York/Oxford: Oxford University Press.

Wildner-Bassett, M.E. (2005). CMC as written conversation: A critical socialconstructivist view of multiple identities and cultural positioning in the L2/C2 classroom. CALICO Journal, 22(3), 365-656.

\section{Author information}

Ana Gimeno is Professor of English Language in the Department of Applied Linguistics at the Universitat Politècnica de València, Spain. She is Head of the CAMILLE Research Group and is Executive Director of WorldCALL, the world organization for Computer-Assisted Language Learning. She is also editor-in-chief of EuroCALL's online scientific journal, The EuroCALL Review and Associate Editor of ReCALL (CUP).

E-mail: agimeno@upvnet.upv.es

To cite this article:

Gimeno, A. (2018). Learner expectations and satisfaction in a US-Spain intercultural telecollaboration project. Bellaterra Journal of Teaching \& Learning Language \& Literature, 11(3), 5-38. DOI: http://doi.org/10.5565/rev/jt13.776 